\title{
GLIMPSES OF GREEN CONSUMERISM AND STEPS TOWARDS SUSTAINABILITY
}

\author{
Dr. Mrudula Trivedi \\ Assistant Professor, Dept. of Commerce and Business Management, \\ Faculty of Commerce, The Maharaja Sayajirao University of Baroda, India
}

\begin{abstract}
The Green Consumerism has emerged world over and slowly changed the ways business used to be practiced. Studies indicate that after 1960s followed by few severe industrial accidents gave rise to Green Movement and at the same time opened vistas for research in green business. Rachel Carson's Silent Spring was one of the pioneering work influenced green movement. Infact, that was the first time pesticides usage and its associated health hazards on human life were studied carefully. One of the landmark work was named "Limits to Growth Report" submitted to the Club of Rome. It projected a catastrophic future if growth continued at the same rate and therefore many groups called for "zero growth". In same time period, IBM had become one of the first companies to establish a formal corporate Environmental Policy and the year 1974 witnessed the Control of Pollution act in the UK, followed by the publication in the UK of the "Green Consumer Guide" in 1988. Literature on Marketing reveals that the concept of green marketing got attention in the 1970s. During mid-1970s, some significant contributions were made on ecological perspectives of marketing.

Several studies were also carried out on green marketing as a potent tool for sustainable development. It was realised that growth with sustainability is most prudent strategy for businesses. Today, organisations have started developing green products, green designs, green technology, environment management as a philosophy, green advertising and greener earth as a business philosophy.
\end{abstract}

Keywords: Green Consumerism, Pollution, Depleted Resources, Green Marketing, Sustainability.

Cite this Article: Dr. Mrudula Trivedi, Glimpses of Green Consumerism and Steps Towards Sustainability, Journal of Management (JOM), 6 (3), 2019, pp. 35-41. http://www.iaeme.com/JOM/issues.asp?JType=JOM\&VType=6\&IType=3

\section{INTRODUCTION}

The concept of "Green Consumerism" has emerged after 1960s. Although it has gone to main stream in advanced countries, it is in the nascent stage in developing countries. The green movement started due to the several industrial accidents which took place in the last three decades. Few significant accidents were Three Mile Island accident at Pennysilvania, Bhopal 
gas tragedy, Exxon Valdez oil spill at Prince William Sound, Alaska, Flixborough disaster of England, and Chernobyl at Soviet Ukraine which caught immense public attention and concern. It gave an insight on the condition of the industry, throwing open the vistas for research studies in this area.

Green marketing literature indicates that Green Consumerism began in the sixties. Studies indicate that Rachel Carson's book titled "Silent Spring" (1962) was the first pioneering work which documented the adverse environmental effects due to use of pesticides. Her book introduced ecology to the public and spurred a spate of legislative activity to protect the environment. ${ }^{1}$ Infact, for the first time, the usage of pesticides and its health hazards on humans were documented and creatively highlighted the importance of 'green and sustainable' before the world.

As cited in Charter Martin's book, the year 1972 saw first ever United Nations conference on the human environment in Stockholm. This conference was an important initiative focusing the interaction of humans and environment and created the United Nations Environment Programme (UNEP). During this time environment and development emerged as important while moving towards growth path. In the same year, in 1972, the "Limits to Growth Report" was submitted to the Club of Rome and emphasised that if our growth pattern is not changed then limits to growth on earth would become evident and it will lead to decline of capacity and economic stability too. It projected a catastrophic future if growth continued at the same rate and therefore many groups called for "zero growth". In 1971, formal corporate Environmental policy, the first of its kind initiative of IBM, in 1974 the Control of Pollution act in the UK, and establishment of the US Environmental Protection Agency took place. The year 1978, was the year of environmental labeling scheme. "The Blue Angel" labelling was conceived in Germany which was followed by Canada, Japan and Sweden in 1980. In the same year Earth day was celebrated for the first time, followed by publishing of World Conservation Strategy by International Union for the Conservation of Nature and Natural Resources (IUCN).published their "World Conservation Strategy". The unprecedented number of major environmental disasters in the seventies and eighties like Three Mile Island, Bhopal, Exxon Valdez, Seveso, Flixborough, and Chernobyl caught the public attention and concern.

The first World Industry Conference on Environmental Management (WICEM I) was held in 1984, with over 500 top industrialists debating environmental issues and business. As a result of WICEM, the International Chamber of Commerce (ICC) established a trans-industry clearing house for environmental management information, the International Environmental Bureau (IBE) ${ }^{2}$

Greener business trends were continuing to develop in Germany also and in 1984, the German Environmentalist Business Management Association (BAOM) was formed as a professional forum designed to examine the practical implication of profitable environmentally responsible business.

In 1987, The United Nations World Commission on Environment and Development recognized that "zero growth" was no longer a viable option if the needs and aspirations of the industrial nations were to be fulfilled. As a result, the year 1987 saw the publication of Our Common Future (The Brundtland Report) which concluded that economic growth had a role to play in improving the standards in the less industrialized world and also in reducing environmental destruction. It suggested that growth had to be of a different order and had to move the world away from viewing the environment as our unlimited resource, to be exploited by each incumbent generation. Thus the concept of modern Sustainable Development was born.

In September 1987, the countries that signed the Montreal Protocol agreed to cut the chlorofluorocarbons (CFC) emissions by half, by the end of the century. The green revolution started in earnest in the UK in 1987 with the Great Storm and the widespread death of seals in 
the North Sea from an unknown disease. Further impetus was added in 1988, with the British Antarctic survey's discovery of the depletion in the ozone layer over the Antarctic. ${ }^{3}$

The Prime Minister of England, Mrs. Thatcher's subsequent speech to the Royal Society on the depth of the environmental problems facing the present and future generations thus then legitimized the debate among many non-environmentalists.

This was followed by the publication in the UK of the "Green Consumer Guide" in 1988, and "The Green Consumer's Supermarket Shopping Guide in 1989", which gave consumers the first real opportunity to look into the back ground of companies that manufactured the socalled "Green" products. ${ }^{4}$

Five years on from the Brundtland Report, the UN General Assembly asked for a report on progress made towards sustainable development and held the Rio Earth Summit. Taking place over 12 days in June 1992 in Rio de Janeiro, Brazil, the Earth Summit was the largest environmental conference ever held.

Five separate agreements were made at the Rio Earth Summit. These included:

- The Convention on Biological Diversity;

- The Framework Convention on Climate change;

- Principles of Forest Management;

- The Rio Declaration on Environment and Development; and

- Agenda 21 (a "blueprint" for sustainable development).

Together these agreements covered every aspect of sustainable development deemed to be relevant. These agreements committed countries, including the UK, to be more sustainable whilst creating guidelines for a more sustainable future.

The first phase of Greener Marketing then moved into gear, driven by a host of conferences and proposed exhibitions. Suddenly, there was a rush of excitement, with the word "green" being daubed in every conceivable place. In the month of June 1983, the word 'green' was used 3617 times in newspapers and magazines. In 1989, these figures had risen to 30,777 times. Similarly, the term "environmentally friendly" was used once in June 1985 and thirty times a day in June $1989 .{ }^{5}$ Some estimates suggest that manufacturers identified nearly $10 \%$ of all new products introduced in 1990 as "green" or otherwise "environmentally friendly." This was more than double the number of green products introduced just one year earlier and about 20 times more than the number of green products introduced in 1985. There was also a dramatic rise in green marketing references in news, business, and trade resources during 1990 and 1991. ${ }^{6}$

Thus, the journey of research in Green Marketing started more than three decades ago and one of the landmark papers published was in the leading UK academic journal. The Journal of Marketing Management published the paper titled, "Has marketing failed or was it never really tried?" penned by a prominent marketing practitioner King. ${ }^{7}$

Literature on Marketing reveals that the concept of green marketing got attention in the 1970s. During mid-1970s, some significant contributions were made on ecological perspectives of marketing. However, only in 1980's did green marketing come into lime light. The 1980's witnessed a rapid increase in green consumerism and green products. In fact, a practical evidence of this came in the form of a highly effective global consumer boycott of C-driven aerosols and the international success of publications such as "The Green Consumer Guide". $(1988)^{8}$

These developments expanded horizons of corporate activities as well as research in the field of green marketing. Researchers started undertaking studies in various areas of green marketing like efforts to identify the ecologically oriented consumer can be found in the 
marketing literature as far back as the early 1970s. Thomas Anderson and William H. Cunningham (1972) undertook a study on "Socially Conscious Consumer". 9 It was found that markets can be segmented on the basis of consumers' social consciousness. Demographic and socio-psychological attributes provided criteria for market segmentation.

It was also found that socially conscious consumers appear to be open-minded, aware and exhibit a general orientation toward progress or change. However, there are many unanswered questions like the willingness of the consumers to pay more for products which enhance social/environmental wellbeing or does their open mindedness result in receptivity to new products which are compatible with the environment or question like which promotional appeals are most effective etc. These questions remained unanswered in this study.

Similarly, a study was conducted on Personality Traits of Ecologically Concerned Consumers (Thomas C. Kinnear, James R. Taylor and Sadrudin A. Ahmed, 1974) ${ }^{10}$ Here, the results indicated that the personality variables were better predictors than the socioeconomic variables. Further, it was found that ecologically conscious consumers are high in openness to new ideas, high in their need to understand the workings of things and they are moderately high in their need to obtain personal safety.

With the passage of time more and more studies were also conducted on Corporate Environmentalism. Here it is worth mentioning the work carried out by Minette Drumwright on "Socially Responsible Organizational Buying: Environmental Concern as a Noneconomic Buying Criterion". (1994) ${ }^{\mathbf{1 1}}$ The said study was conducted with MNCs and their operations in the U.S. The findings revealed that the zeal for socially responsible buying is rooted in a commitment based on a complex and an often-difficult process of moral reasoning. In the year 1997, a study was carried out by Ajay Menon \& Anil Menon on "Environpreneurial Marketing Strategy: The Emergence of Corporate Environmentalism as Market Strategy"12 and they identified that slowly but surely, consensus has emerged among corporate leaders that social goals and business success are very much interwoven. In fact, business planning should be linked to environmental concern. Thus, some studies were undertaken in this area as well.

Several studies were also carried out on green marketing as a potent tool for sustainable development. Few are mentioned here. "It's not easy being green" (Walley, Noah and Bradley Whitehead, (1994) $)^{\mathbf{1 3}}$ in which it is mentioned that economic growth and environmental protection are inextricably linked.

One significant study was undertaken by Michael Porter in the area titled, "Green and Competitive: Ending the Stalemate” (Porter Michael E. and Class Van De Linde 1995). ${ }^{\mathbf{1 4}}$ Here, authors argued that how an industry responds to environmental problems may, in fact, be a leading factor of its overall competitiveness. Traditionally, nations were competitive if their companies had access to the lowest cost inputs like capital, labor, energy and raw materials. However over a period of time, it was found that the nations and companies that are most competitive are not those with access to the lowest cost inputs but those that employ the most advanced technology and methods in using their inputs. The new paradigm of global competitiveness requires the ability to innovate rapidly. This new paradigm has brought environmental improvement and competitiveness together.

Very interesting and useful study was carried out in the year 1997, by Hart and Stuart, which is worth mentioning here titled "Beyond Greening: Strategies for a Sustainable World". ${ }^{15}$ The authors herein argue that "Greening" has been framed in terms of risk reduction, re-engineering or cost cutting. Rarely is greening linked to a strategy or technology development and as a result, most companies fail to recognize the opportunities of potentially staggering proportions.

One research study had also been conducted with reference to "Marketing of Electric Vehicles". (Anita Garling and John Thogorsen 2001) (6) $^{\mathbf{6}}$ Although it is useful and gives insight about issues related to electric vehicles, results of this study cannot be generalized as it is 
conducted for a car and not a two wheeler. However, this study has definitely provided insight on problems pertaining to battery performance.

\section{GROWTH WITH ITS ADVERSE EFFECTS}

Over the year's economic growth and development, profits and customer satisfaction have been the goals of organizations. However, it is also learned that the journey of growth is proved very costly for the society at large. It is bringing intense pollution and spreading its adverse effects too. This growth is not sustainable. It has its own side effects which needs to be minimized. Sector wise when we see oil, textiles, electronics, leather, automobiles and transportation etc. have been discharging huge pollution leaving its black foot prints on green earth.

Industrial waste is huge and emitted in an irresponsible way. Furthermore, it is also depleting the natural resources. In fact, pollution is has significantly damaged our environment. This growth without sustainability is not desirable. This is the realization by corporates, government, N.G.Os and consumers at large.

\section{SUSTAINABILITY METHODS AND CONCEPTS ADOPTED}

\section{Green Product Design}

Now in various sectors corporations have started emphasizing green product designs. Electric two wheelers, chemical free detergent powder, Green fabric, battery operated bicycles, solar energy and solar powered gadgets, electric gadgets consuming less electricity, eco-tourism.

\section{Green Competencies}

Organizations focus more on building its green competencies by investing in Research and Development in environment friendly products. Similarly, employee sensitivity is being increased towards environment. Hence, skills and abilities are sharpened towards contribution in environment protection.

\section{Recognising Environmental Management as a key priority in organization}

Organisation's top management have started regarding and respecting environment and exhibiting long term commitment towards its protection along with profit and customer satisfaction.

\section{Green Advocates}

In order to contribute positively for environment protection, key persons from NGOs, film industry, corporate world are taking lot of initiatives to communicate and to persuade people for green consumption and green culture.

\section{Environmental Impact Assessment}

It is being realized that product design or processes should not discharge harmful gases in the atmosphere, should consume less energy and associated wastage of raw material should be minimum. Henkel is one organization which is proactive and implements green practices for sustainability.

\section{Green Advertising}

Digital media and its emergence over the years has offering new ways of advertising against traditional print and air media. Furthermore social media advertising is economical too. So, today organizations are exploiting green adverting opportunities when they find appropriate target market.

\section{Presence of Green Vision and Values}

Today's organizations are performing and improvising continuously with green vision and values as its core philosophy. Henkel is focusing on green technology, focusing more on safety and health of employees and environmental care is its worldwide initiative. 


\section{CONCLUSION}

Green Consumerism offered new ways of doing business and thinking about the future first. Organisations world over started exploiting new opportunities for business by gearing up towards eco innovations and adopting green culture. Environmental Progrmmes at AT \& T, General Electric Pollution, Waste, and Emissions Reduction Program (POWER, 1989), Goodyear Toxic Air Emissions Reduction, IBM Hazardous Waste Elimination Programme, Henkel's worldwide programmes dedicated to environment protection are few examples of organizations moving towards sustainability and responded well with the emergence of green consumerism.

\section{REFERENCES}

[1] Polonsky Michael J., Environmental Marketing, Jaico Publishing House, Mumbai, P-59.

[2] Charter Martin, Greener Marketing: A Responsible Approach to Business, GreenleafPublishing (1992), England, P-14-15.

[3] Charter Martin, Greener Marketing: A Responsible Approach to Business, Greenleaf Publishing (1992), England, P-15.

[4] Charter Martin, Greener Marketing: A Responsible Approach to Business, Greenleaf Publishing (1992), England, P-15.

[5] Charter Martin, Greener Marketing: A Responsible Approach to Business, Greenleaf Publishing (1992), England, P-15-16.

[6] Polonsky Michael J., Environmental Marketing, Jaico Publishing House, Mumbai, P-3-4.

[7] Sheenu Jain, Green Marketing: An Illusion or reality, Indian Journal of Marketing, May $2007, \mathrm{P}-17$.

[8] Sheenu Jain, Green Marketing: An Illusion or reality, Indian Journal of Marketing, May $2007, \mathrm{P}-17$.

[9] Anderson W. Thomas, Jr. and William H. Cunningham, The Socially Conscious Consumer, Journal of Marketing, 36, No. 3, July 1972, P - 46-57.

[10] Thomas C. Kinnear, James R. Toylor and Sadrudin A. Ahmed, Personality Traits of Ecologically Concerned Consumers: Who Are They? Journal of Marketing, Vol. 38, April 1974, P - 20-24.

[11] Minette E. Drumright, Socially Responsible Organizationl Buying : Environmental Concern as a Noneconomic Buying Criterion, Journal of Marketing, Vol. 58, No. 3 July 1994, P - 1-19.

[12] Menon Ajay and Menon Anil, Environpreneurial Marketing Strategy: The Environmentalism as Market Strategy, Journal of Marketing, Vol. 61, No.1, January 1997, P- 51-67. 
[13] Walley, Noah and Bradely Whitehead, It's Not Easy Being Green, Harvard Business Review, May/June 1994, P-46-52.

[14] Porter Michael E. and Class van De Linde, Green and Competitive: Ending the Stalemate, Harvard Business Review, September-October 1995, P-120-134

[15] Hart Stuart Beyond Greening: Strategies for a Sustainable Development, Harvard Business Review, 75, January/February, P-67-76.

[16] Garling Anita and Thogersen John, Marketing of Electric Vehicles, Business Strategy and the Environment,Vol.10, No.1, January-February 2001, P-53-65. 